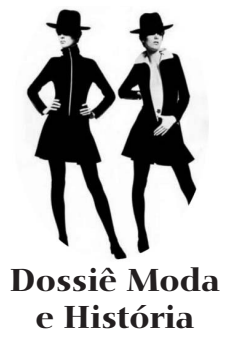

ARTIGO

Contato

Rua Dorvalina Machado Coelho, 99 88030-530 - Florianópolis - Santa Catarina sant.anna.udesc@gmail.com

\section{O MASCULINO NOS TRAÇOS E CORES DO JOVEM VICTOR MEIRELLES*}

\section{- Mara Rúbia Sant'Anna**}

Universidade do Estado de Santa Catarina

Florianópolis - Santa Catarina - Brasil

\title{
Resumo
}

Este artigo faz uma discussão dos tipos masculinos presentes na coleção Estudo de trajes italianos, produzida por Victor Meirelles, analisando: aspectos quantitativos da iconografia associada aos gêneros; os ícones da aparência corporal recorrentes na caracterização das figuras masculinas da coleção e, por fim, a relação dessas representações com as narrações vestimentares vigentes para o masculino no mesmo período histórico, levando em conta os livros de história da moda atuais, por meio de suas escritas e ilustrações. Na estrutura argumentativa, posiciona-se diante das imagens considerando as relações discursivas presentes, fomentadas por tempos distintos e intermitentes de narração visual. Com esse propósito, esperase contribuir para alargar a compreensão da história do vestir masculino ocidental e promover uma leitura mais crítica da bibliografia atual sobre o passado vestimentar, e do uso das produções artísticas do passado em narrativas do presente.

\section{Palavras-chave}

Victor Meirelles - traje masculino - narrativas vestimentares - estudo de trajes - história da moda

\footnotetext{
* Pesquisa financiada pelo Conselho Nacional de Desenvolvimento Científico e Tecnológico CNPq, bolsa de pós-doutorado sênior, nov. 2016 a out. 2017.

** Doutora em História pela Universidade Federal do Rio Grande do Sul, pós-doutora em História pela Université de Strasbourg, pós-doutorado em Artes Visuais pela Universidade Federal do Rio de Janeiro e professora efetiva da Universidade do Estado de Santa Catarina.
} 


\section{(⿻) \\ Fashion and \\ History Dossier}

Contact

Rua Dorvalina Machado Coelho, 99 88030-530 - Florianópolis - Santa Catarina sant.anna.udesc@gmail.com

\section{THE MASCULINE IN THE TRAITS AND COLORS OF THE YOUNG VICTOR}

\section{MEIRELLES}

\section{- Mara Rúbia Sant'Anna}

Universidade do Estado de Santa Catarina

Florianópolis - Santa Catarina - Brasil

\begin{abstract}
This text discuss the masculine types present in the collection of Italian costumes, produced by Victor Meirelles, analyzing: quantitative aspects of the iconography associated with the genres; the recurring icons of body appearance in the characterization of the male figures in the collection and, finally, the relation of these representations with the current vestiges narratives for the masculine in the same historical period, taking into account the current history books of fashion, through his writings and illustrations. In the argumentative structure it is positioned before the images considering the present discursive relations, fomented by distinct and intermittent times of visual narration. With this purpose it is hoped to contribute to broadening the understanding of the history of western male dress and to promoting a more critical reading of the current bibliography on the past dress and the use of the artistic productions of the past in narratives of the present.
\end{abstract}

\title{
Keywords
}

Victor Meirelles - masculine costumes - dress narratives - study of costumes fashion history 
O presente texto resulta de proposta de investigação que buscou ultrapassar a descrição factual de feitos e conquistas de um artista renomado como Victor Meirelles, ${ }^{1}$ a fim de compreender as relações discursivas que se impõem entre o produzido e o vivido por um sujeito social há mais de um século e o olhar contemporâneo. Ao observar o objeto desta pesquisa, não houve um estranhamento, mas uma identificação rápida e fácil dos gêneros humanos e de traços e volumes que representam trajes e adereços localizados no século XIX ocidental. Todavia, entende-se que, diante da imagem, a ação de olhá-la nos desperta evocações do visto e, por isso, impõem-se relações discursivas entre tempos distintos (DIDI-HUBERMAN, 2015). ${ }^{2}$ É sobre um ritmo de três tempos distantes e distintos, mas sobrepostos e intervenientes, que a pesquisa foi delineada. Essas relações discursivas são propostas entre um sujeito/tempo passado que produziu, mediante intericonidades ${ }^{3}$ e intertextualidades próprias de sua formação e época - Victor Meirelles -; um conjunto de agentes/tempo presente que foi armazenado, catalogado e conservado, possibilitando o acesso no agora - Museu Victor Meirelles, Museu Nacional de Belas Artes e colecionadores -; e um resultado/tempo perene, quantificável e palpável, sobre o qual referentes indicam uma pre-

\footnotetext{
1 Segundo Donato Mello Júnior (1982), em seu levantamento bibliográfico a respeito de Victor Meirelles, o estudo mais antigo feito sobre o artista data de 1872. Produzido por Giorgio Vasaru, consistiu na análise comparativa da batalha de Campo Grande e da batalha naval do Riachuelo produzidas, respectivamente, por Pedro Américo e Victor Meirelles. Cf. MELLO JÚNIOR, Donatto. Análise da composição. In: ROSA, Ângelo de Proença छ PEIXOTO, Elza Ramos. Victor Meirelles de Lima: 1832-1903. Rio de Janeiro: Pinakotheke, 1982, p. 117-121. Dentre os biógrafos, pode-se citar Max Fleiuss que publicou, em 1905, texto com o título "Vitor Meirelles". Também Adalberto Matos, em 1925, publica "O pintor Vítor Meirelles de Lima". Porém um dos biógrafos mais citado em outros trabalhos é Carlos Rubens. Em 1945, a Imprensa Nacional publicou "Vítor Meirelles, sua vida e sua obra". Diversos trabalhos acadêmicos e artigos científicos foram publicados a respeito das obras artísticas de Victor Meirelles e sobre a sua vida. Mais recentemente destacam-se os trabalhos de COLI, Jorge. Pedro Américo, Victor Meirelles, entre o passado e o presente. Caiana - Revista de Historia del Arte y Cultura Visual del Centro Argentino de Investigadores de Arte, vol. 3, 2013, p. 1-8, e COELHO, Mário Cesar. Os panoramas perdidos de Victor Meirelles: aventuras de um pintor acadêmico na modernidade. Tese de doutorado, Universidade Federal de Santa Catarina, Florianópolis, 2007.

2 DIDI-HUBERMAN, Georges. Ante el tiempo: historia del arte y anacronismo de las imágenes. 4 a edição. Buenos Aires: Adriana Hidalgo, 2015.

3 Segundo conceitos de PIROTTE, Jean. Images et critique historique. In: JADOULE, Jean-Louis. L'histoire au prisme de l'image, vol. 1: L'historien et l'image fixe texte. Louvain/BG: Université Catholique de Louvain, 2002, e COURTINE, J.-J. Foucault e a história da análise do discurso, olhares e objetos. Entrevista concedida a Nilton Milanez. In: FERNANDES, C. A.; CONTI, A.; MARQUES, W. (org.). Michel Foucault e o discurso: aportes teóricos e metodológicos. Uberlândia: Edufu, 2013.
} 
sença, um trabalho e um valor estético, histórico e cultural: as 159 pranchas que compõem o corpus desta pesquisa.

Não estão presentes neste artigo todos os resultados alcançados na pesquisa, mas pretende-se evidenciar a representação do gênero masculino que Victor Meirelles produziu nessa coleção e, ainda, discutir outras narrativas associadas ao vestir masculino que perpetuam maneiras de vê-lo. Ou seja, o artigo se ateve a um aspecto de intericonicidade (PIROTTE, 2002) ${ }^{4}$ - a figura masculina - e a uma intermitência de tempo passado/presente: o registro artístico que as pranchas possuem e as narrativas do vestir sobre este tempo passado que repercutem no presente pela escrita e ilustrações de livros de história da moda.

Portanto, o artigo se estrutura em três partes. A primeira caracteriza a produção em estudo integrando-a às tendências artísticas e culturais de sua época e apresentando sua descrição geral e quantificação do conteúdo iconográfico por gêneros. A segunda se atém à análise dos ícones de aparência corporal atribuídos às figuras masculinas representadas pelo artista e, por fim, a terceira compara as representações do masculino contidas nas pranchas com outras narrativas visuais e escritas de alguns livros de história da moda.

\section{A coleção}

O Estudo de trajes italianos configura um conjunto de obras realizadas por Victor Meirelles entre os anos de 1853 e 1856, conforme datação oficial, ${ }^{5}$ enquanto estava estudando na Itália graças à bolsa de estudos que ganhou como prêmio 6 do concurso anual da Academia Imperial de Belas Artes em 1852. As obras consistem de desenhos de figuras humanas vestidas com trajes que a nomenclatura atual facilmente denominaria de folclóricos. A maioria das figuras tem objetos desenhados em suas mãos ou determinadas peças de vestuário como aventais, batinas, calças de couro etc., indicando

\footnotetext{
${ }_{4}$ PIROTTE, Jean. Images et critique historique, op. cit., 2002.

5 Ângelo de Proença Rosa e Elza Ramos Peixoto desenvolveram uma biografia sucinta de Victor Meirelles dividida em quatro fases, sendo elas: fase catarinense (1832 - 1846); fase escolar (1847 - 1853); fase do prêmio de viagem (1853 - 1861) e fase da plenitude (1861 - 1890). Cf. ROSA, Ângelo de Proença \& PEIXOTO, Elza Ramos. Biografia, op. cit., In: Idem. Victor Meirelles de Lima: 1832-1903. Rio de Janeiro: Pinakotheke, 1982.

6 Sônia Gomes Pereira relata, no derradeiro capítulo de seu livro Arte, ensino e academia..., os prêmios de viagens e a importância desses na formação dos artistas da Academia Imperial de Belas Artes. Cf. PEREIRA, Sonia Gomes. Arte, ensino e academia: estudos e ensaios sobre a Academia de Belas Artes do Rio de Janeiro. Rio de Janeiro: Mauad/Faperj, 2016.
} 
trabalhos ou atividades peculiares. Apenas duas aquarelas coloridas possuem duas figuras juntas.

\section{Figura 1}

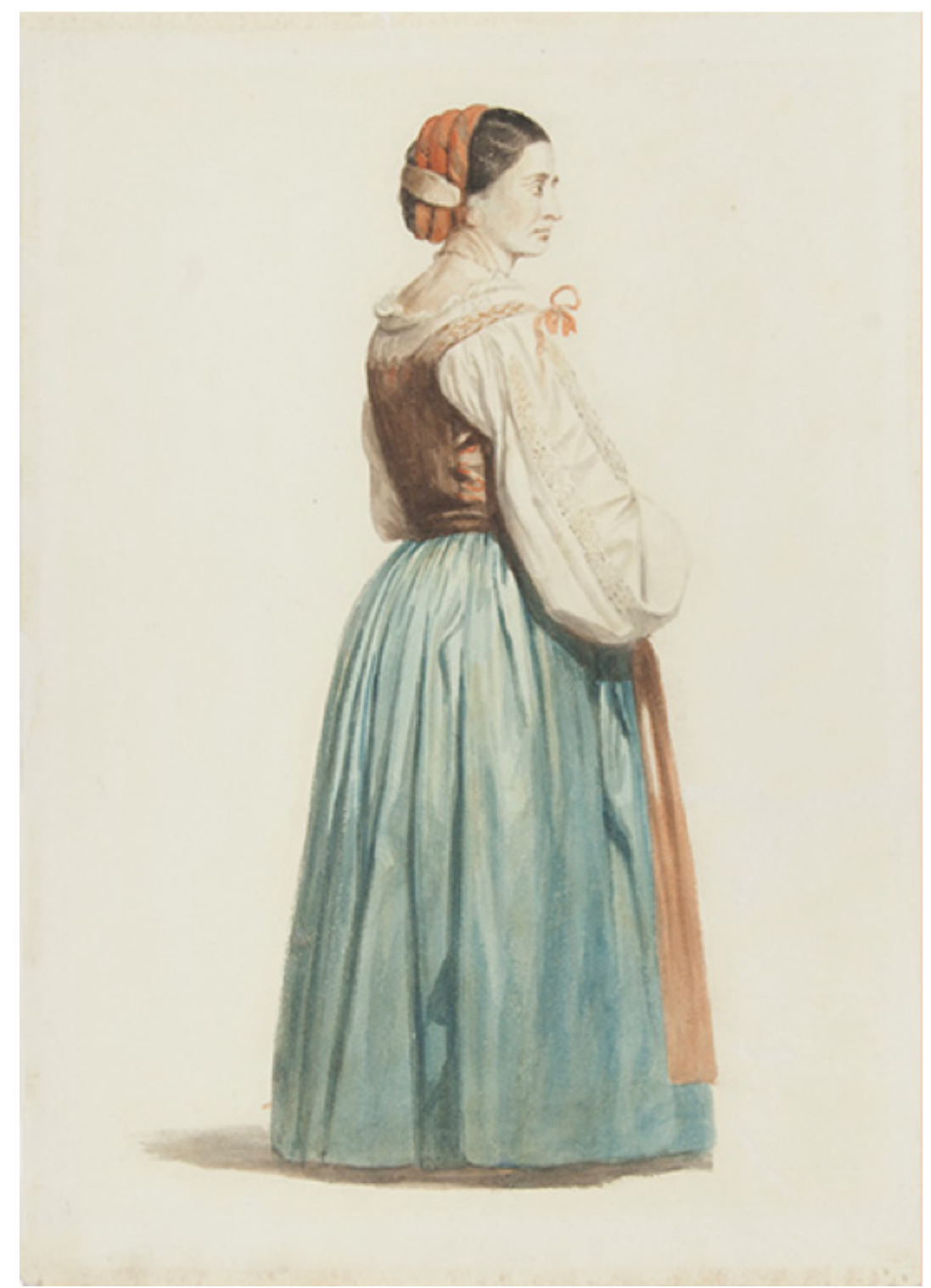

MEIRELLES, Victor. Estudo de traje italiano. MVM 052. 1853 -1856.

Aquarela sobre papel, 29,2 x 20,8 cm. Fonte: Museu Victor Meirelles. 
Ainda sobre as características das pranchas, acrescenta-se que as obras dessa série não foram produzidas com os mesmos materiais, sendo, a maioria, pinturas feitas em aquarela sobre papel, contudo há gravuras feitas com grafite, a óleo, entre outras técnicas. O formato que predomina nas pranchas é retangular, com tamanho em torno de $35 \mathrm{~cm}$ por $20 \mathrm{~cm}$, tendo alguns centímetros de variações. Todavia, há três com formatos especiais: uma redonda e duas ovaladas. Essas não ultrapassam os $15 \mathrm{~cm}$ de altura ou diâmetro.

Não há um número exato de quantas produções compõem a coleção Estudo de trajes italianos, já que algumas se perderam ao longo dos anos e muitas fazem parte de coleções particulares. Porém, conforme levantamento realizado pelo Museu Victor Meirelles por meio de projeto específico, ${ }^{7}$ há no Brasil um pouco mais de uma centena dessas pranchas em cores: uma parte encontra-se no Museu Victor Meirelles (21 pranchas) e outra, no Museu de Belas Artes do Rio de Janeiro (72 pranchas), dez com um colecionador particular catarinense e mais uma com outro colecionador paulista. Se forem considerados as pranchas não coloridas ou os desenhos em papel ordinário, mas que contenham a denominação "trajes" ou "costume" e, ainda, os estudos de planejamento, ${ }^{8}$ a soma chega a 169 artefatos. Assim, resumindo, temse hoje catalogados pelos museus Victor Meirelles e Nacional de Belas Artes:

- Pranchas coloridas: 104;

- Desenhos em preto e branco com tema de trajes e costumes: 45; e

- Estudos de planejamentos: 20.

Como não há qualquer estudo a respeito dos trajes desenhados por Victor Meirelles que os tenha catalogado e descrito, o trabalho inicial da pesquisa foi exatamente esmiuçar o conteúdo iconográfico a partir de alguns critérios de classificação, amadurecendo o olhar investigador como os aportes teóricos recomendam. A pesquisa foi iniciada pelo detalhamento do conteúdo visual das pranchas apresentadas num catálogo produzido pelo Museu Victor Meirelles em 2006, que contém 26 ilustrações. ${ }^{9}$ Em novembro de 2016, o Museu

\footnotetext{
7 Estudo coordenado pela diretora do MVM, Lourdes Rosseto, entre 2008 a 2009.

8 Não há explicações claras relativas à denominação dos trabalhos encontrada nas fichas catalográficas junto aos acervos pesquisados, ou seja, não se sabe ao certo se as denominações foram definidas pelo próprio pintor ou a posteriori pelos funcionários responsáveis pelos acervos. O que se pensa, a partir das práticas museológicas, é que as denominações e os agrupamentos foram realizados pelas equipes responsáveis pelos museus sendo reformuladas em diferentes situações.

9 O estudo consistiu na análise das pranchas a partir de seis quesitos: ambiência, posição, corpo, trajes, cores e formas; partes do estudo foram publicadas em alguns anais ena coletânea do $6^{\circ}$ ENPModa, 2016.
} 
Nacional de Belas Artes cedeu uma cópia digital do seu acervo, catalogada como Estudo de trajes e, posteriormente, essas imagens foram impressas e estão em permanente estudo, classificação e agrupamentos por diferentes critérios. A metodologia da "montagem" empregada visa a provocar novos olhares, estranhamentos e produção de novas perspectivas e sentidos sobre esse acervo. Como deixa dito Didi-Huberman, o método da montagem consiste numa disposição de pensar a copresença ou a coexistência de diferentes aspectos sob o ângulo dinâmico do conflito e, para tanto, necessário é "dispor as coisas, desorganizar sua ordem de aparição. Maneira de mostrar toda disposição como um choque de heterogeneidades" (DIDI-HUBERMAN, 2009, p. 86). ${ }^{10}$

Apesar de, à primeira vista, parecer que o detalhamento visual realizado seja quantitativo demais e, talvez, até desnecessário ou primário, tem-se a certeza de que, apenas a partir de uma desnaturalização do conjunto de pranchas, quantificando seus aspectos - sem perder de vista que se trata de representações visuais e não de mulheres e homens que num determinado momento viveram - pode-se chegar ao limiar da porta (DIDI-HUBERMAN, 2010). ${ }^{11}$ que a imagem entrevê e fazer uma aproximação mais cuidadosa dos sentidos e possibilidades de leitura que as composições de cores, formas, linhas e representações ensejam ao nosso olhar no contemporâneo. Mesmo que seja de incompletude que o processo se realize, a tentativa é a própria experiência do conhecer.

Pois essa porta permanece diante de nós para que não atravessemos seu limiar (...). Permanentemente à orla (...). Nessa situação, somos ao mesmo tempo forçados a uma passagem que o labirinto decidiu por nós e desorientados diante de cada porta, diante de cada signo de orientação. Estamos de fato entre um diante e um dentro. E essa desconfortável postura define toda a nossa experiência, quando se abre em nós o que nos olha no que vemos (DIDI-HUBERMAN, 2010). ${ }^{12}$

Imbuída desse "diante e dentro", foi realizado um segundo processo de classificação das imagens em 2017, considerando o total de 104 pranchas coloridas sob os seguintes eixos: gênero, posição corporal, presença de objetos de trabalho, conforme gênero e expressão de faixa etária. Desse estudo explo-

\footnotetext{
${ }^{10}$ DIDI-HUBERMAN, Georges. Quand les simages prennent position: l'oeil de l'histoire, vol. 1, capítulo 2: La dysposition des choses: démonter l'ordre. Paris: Les èditions de Minuit, 2009, p. 86.

${ }^{11}$ DIDI-HUBERMAN, Georges. O interminável limiar do olhar, capítulo 10: O que vemos, o que nos olha. São Paulo: Ed. 34, 2010.

${ }^{12}$ Ibidem, p, 234.
} 
ratório, alcançou-se o escopo de análise quanto ao gênero masculino e, com a identificação feita, confrontaram-se as narrativas vestimentares associadas a ele. O percurso metodológico de investigação das pranchas agrupadas em "estudos de trajes italianos", como descrito acima, permitiu a discussão no campo historiográfico que ora se apresenta. Trata-se de evidenciar os ícones associados ao gênero masculino que o trabalho artístico traz sem anular essa sua condição para então discutir outras narrativas do vestir que, carregadas de simplificações e redundâncias, perpetuam maneiras de ver o passado.

\section{Tradição narrativa do vestir}

Esse tipo de produção artística foi muito comum naquele momento histórico em que, ao sabor de um espírito romântico em busca do autêntico e original de outras épocas, artistas dedicavam-se a pintar figuras humanas vestidas em trajes típicos, caracterizando diferentes regiões. As viagens à Itália em busca do pitoresco foram um roteiro desejado pela elite letrada do século XIX e esses primeiros turistas levavam consigo, ao partir, pequenas pranchas em que o registro do particular e antigo soava como cultura. Nas palavras de Ottavio Lurati:

A sensação da viagem, a esperança do diverso, do desconhecido e do distante, que alimentou a atenção da nascente ciência geográfica e etnográfica, são alguns dos motivos que podem nos guiar ao documento ou, sobretudo, ao material relativo ao vestir da gente no século passado. As descobertas e explorações geográficas que se seguiram nos séculos XVI e XVII intensificaram um gênero, qual seja o do livro de viagem, em que, ao lado da descrição de terras e povos exóticos, a representação da roupa regional também encontrou seu lugar. (LURATI \& BOLLA, 1990, p. 17) ${ }^{13}$

Silvestrini (1986, p. 5-44), ${ }^{14}$ por sua vez, aponta que, desde o século XVI, a produção desses desenhos de trajes regionais foi comum e nisto se destacaram: Enea Vico, Ferdinando Bertelli, Jos Amman e Hans Weigel, Abraham de Bruyn, Boissard, Pietro Bertelli e Cesare Vecellio. Este último é o mais conhecido dos historiadores brasileiros.

No século XIX, essa prática artística, nascida há tantos séculos, ainda se mantinha viva e mesmo reforçada com os princípios da escola purista (SCAR-

\footnotetext{
${ }^{13}$ LURATI, Ottavio E B BOLLA, Stefano. L'œimmagine della tradizione: ideologia e storia nel costume popolare: con la riproduzione di rari esempi ticinesi e svizzeri. Milão: Il Polifilo, 1990, p. 17.

14 SILVESTRINI, Elisabetta. L'abbigliamento popolare italiano. Ricerca Folklórica, n. 14, 1986, p. 5-44.
} 
PA, 1959, p. 235-242) ${ }_{1}^{15}$ constituída em Roma e liderada por Minardi, professor da Academia de São Lucas a quem Meirelles fora recomendado. Entre os puristas, Bartolomeo Pinelli (1781-1835) destacava-se por também produzir pranchas de trajes típicos. Ele foi um exímio desenhista, frequentemente comparado a John Flaxman (1755-1826), purista consagrado do solo inglês, conforme Barilli. ${ }^{16}$ Esse artista italiano se imortalizou na história da arte de seu país ao desenvolver as ilustrações para os livros de História de Roma (1816) e História grega (1821), outros de literatura clássica, como Odisseia, Eneida e Ilíada e, ainda, por ter feito publicar em um álbum trinta e seis aquarelas de cenas e costumes de Roma e Lazio em 1807. Em 1809, produziu a série de gravuras Cinquenta trajes pitorescos ${ }^{17}$ publicada por Lorenzo Lazzari alle Converlille. Nesses mesmos anos, Debret fez uma estada em Roma e produziu trabalho semelhante: um livro de estampas intitulado Costumes italiens, publicado por L.F. Petit.18

\section{Figura 2}

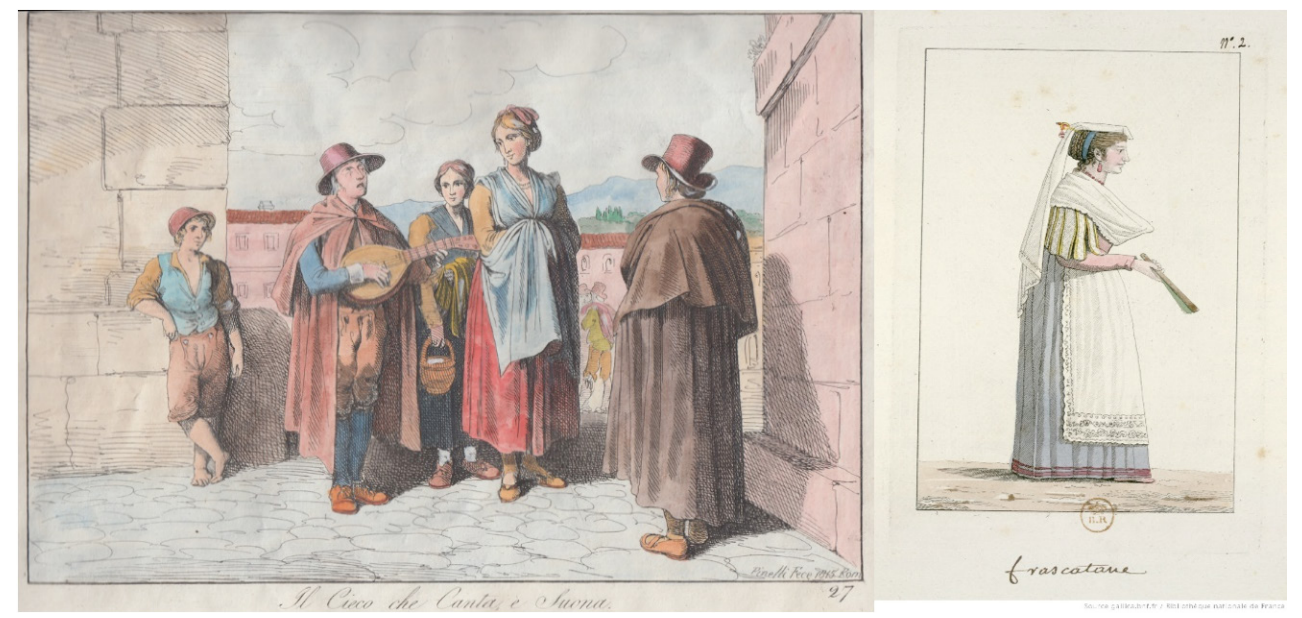

PINELLI, Bartolomeo. Il Cieco che canta e suona, 1815. Aquarela sobre papel, prancha 27. DEBRET, Jean-Baptiste. Frascatane, 1809. Aquarela sobre papel, prancha 2. Fonte: www.gallica.bnf.fr/catalogue.

\footnotetext{
${ }^{15}$ SCARPA, Piero. La scuola romana di Tommaso Minardi segnò la fine in Europa del neoclassicismo in arte. Strenna dei Romanisti, n. 20, 1959, p. 235-242.

${ }^{16}$ BARILLI, Renato. Storia dell'arte contemporanea in Italia: da Canova alle ultime tendenze, 1789-2006. Turim: B. Boringhieri, 2007.

${ }^{17}$ ROSSETTI, Bartolomeo. La Roma di Bartolomeo Pinelli: una città e il suo popolo attraverso feste, misteri, ambienti e personaggi caratteristici nelle più belle incisioni del pittor de Trastevere. Roma: Newton Compton, 1981.

${ }^{18}$ DEBRET, Jean-Baptiste. Costumes italiens dessinés à Rome en 1807. Paris: Louis-Marie Petit, 1809.
} 
O livro publicado em 1971 - Costumi di Roma e dintorni: 24 acquerelli dela meta dell'Ottocento ${ }^{19}$ - reúne pranchas encontradas num acervo do papa Pio IX. Como o título informa, trata-se de aquarelas das cidades vizinhas de Roma. Na apresentação do livro, feita por Valério Mariani, ${ }^{20}$ está indicado que, apesar da falta de assinaturas nas aquarelas, as mesmas poderiam ser atribuídas a Pinelli ou a um de seus discípulos, pois o conhecido ilustrador havia feito escola com as aquarelas de costumes populares italianos no século XIX. Discorre, ainda, sobre o hábito já instituído de se produzir aquarelas com a temática regional, a fim de presentear estrangeiros ou de estes as comprarem para levar de lembrança às suas terras de origem:

Em Roma, especialmente, onde muitos estrangeiros se encontraram realizando a tradicional "viagem romana", quase obrigatória para as pessoas de certa cultura, a voga de adquirir desenhos em que se observavam as formas características do povo e dos camponeses dos arredores favoreceu o desenvolvimento destas gravuras adquiridas como uma lembrança do período que passaram na cidade papal: ao mesmo tempo, muitos estudantes estrangeiros desenharam e fizeram aquarelas dos trajes coloridos e dos penteados que também podiam ser encontrados na cidade (...) (MARIANI, 1971, p. 6). ${ }^{21}$

Logo, na produção das pranchas deixadas por Meirelles fica evidente uma filiação a essa tradição tão própria aos viajantes e estudantes de Roma, em que figuras humanas são representadas em primeiro plano com trajes expressivos da região e da cultura. Todavia, Meirelles, diferente do que se tem observado nos trabalhos acima citados, produziu a mesma temática, mas com pinceladas tênues na busca precisa do panejamento e das variações possíveis de um corpo em movimento. Por isso, cogita-se que duas motivações envolveram Victor na produção das pranchas: por um lado, a possibilidade de comercialização desse trabalho, tão requisitado pelos viajantes e, de outro, a necessidade de aperfeiçoar o exercício do panejamento, comum na formação artística ${ }^{22}$ oferecida à época. Ao mesmo tempo, a temática central dos usos e costumes do homem comum da época era adicionada

\footnotetext{
${ }^{19}$ MARIANI, Valerio (apresentação). Costumi di Roma e dintorni: 24 acquerelli della meta dell'Ottocento. Curadoria da edição de Roberto Peliti. Roma: Stabilimento Tipografico Julia, 1971.

${ }^{20}$ Importante historiador da arte e crítico, com pequena produção bibliográfica, mas de grande repercussão como conferencista. Sobrinho do artista Cesare Mariani e filho do conhecido arqueólogo Lucio Mariani. Nasceu em Roma em 1899 e morreu em 1982.

${ }^{21}$ MARIANI, Valerio (apresentação). Costumi di Roma e dintorni, op. cit., 1971, p. 6.

${ }^{22}$ Ver LE CHANU, Patrick. Le drapé: carnet de dessins. Paris: La Bibliothèque de l'Iimage, 2002. Sobre a formação artística do período ver: FUGIER, Anne Martin. La vie d'artiste au XIX siécle. Paris: Audibert, 2007.
} 
de uma preocupação com o uso das cores, posições e expressões nas figuras imbuídas de carga emotiva, fazendo referência direta aos temas românticos ${ }^{23}$ do século XIX, ao que se soma uma terceira motivação para a execução do estudo de trajes regionais: a intenção de compor um álbum particular com o gênero de imagens, acervando um repertório importante para si.

Nessa análise cabe, adequadamente, a categoria de intericonicidade, definida a partir dos conceitos de intertextualidade, provindos da linguística de Julia Kristeva. Da mesma maneira que se concebe que a palavra é diálogo com outro econsigo mesmo, asimagens sãotambém dialógicas. Assimafirma Pirotte:

Como todo texto, toda imagem se inscreve numa sequência de imagens; trazidas de um contexto sociocultural, toda imagem é composição que se baseia sobre aquisições anteriores. A noção de intericonicidade se religa facilmente a essa intertextualidade para explorar as relações manifestas ou secretas ligadas às imagens (PIROTTTE, 2002, p. 21). ${ }^{24}$

E concluindo sua conceituação ele diz: "Toda imagem deve ser olhada à luz da memória iconográfica". ${ }^{25}$

Aprofundando o conceito inicial, Jean-Jacques Courtine afirma que "toda imagem se inscreve numa cultura visual, e esta cultura supõe a existência, junto ao indivíduo, de uma memória visual, de uma memória das imagens onde toda memória tem um eco" (COURTINE, 2013, p. 43). ${ }^{26}$ Esta ideia tem fundamento a partir da noção de interdiscursos de Pêcheux que diz: “(...) o interdiscurso enquanto discurso-transverso atravessa e põe em conexão entre si os elementos discursivos constituídos pelo interdiscurso enquanto pré-construído, que fornece, por assim dizer, a matéria-prima na qual o sujeito se constitui como sujeito falante" (PÊCHEUX, 1997, p. 167). ${ }^{27}$

Logo, admite-se que toda imagem, no caso os estudos de trajes produzidos por longa data, tenha inscrição numa cultura visual e, por conta dessa sua origem, tanto as imagens como os objetos e até os comportamentos devem ser tratados a partir de uma extensa rede de significações. Tal experiência social produz nos sujeitos memórias sociais que os alfabetizam, entre outras coisas, para ler e compreender o mundo por imagens. Assim,

\footnotetext{
${ }^{25}$ Ver GUINSBURG, J. (org.). O romantismo. 4 edição. São Paulo: Perspectiva, 2011.

${ }^{24}$ PIROTTE, Jean. Images et critique historique, op. cit., 2002, p. 21.

${ }^{25}$ Idem.

${ }^{26}$ COURTINE, J.-J. Foucault e a história da análise do discurso, olhares e objetos, op. cit., 2013, p. 43.

${ }^{27}$ PÊCHEUX, Michel. Análise automática do discurso. In: GADET, Françoise \& HAK, Tony (org.). Por uma análise automática do discurso: uma introdução à obra de Michel Pêcheux. Campinas: Editora da Unicamp, 1997, p. 167.
} 
os artistas do século XIX, entre eles o brasileiro Victor Meirelles, se constituíram, também, mediante a cultura visual vinculada aos estudos dos trajes italianos encontrados desde $1423 .^{28}$

\section{Aspectos quantitativos e representação dos gêneros em relação ao trabalho}

São no total 70 figuras femininas, sendo que cinco pertencem a colecionadores particulares; dezenove ao acervo do Museu Victor Meirelles e quarenta e seis ao acervo do Museu Nacional de Belas Artes. As figuras masculinas compõem um conjunto de 36 , sendo seis pertencentes a colecionadores particulares, duas ao acervo do Museu Victor Meirelles e 28 ao acervo do Museu Nacional de Belas Artes. Se forem somados os números apresentados, observa-se que o total ultrapassa a indicação de 104 pranchas coloridas, mas isto se deve ao fato de que, em duas delas, há uma dupla de figuras, sendo a MNBA 1579 composta por duas figuras femininas e a MNBA 1578 por um casal.

Boa parte das figuras representadas - considerados ambos os gêneros - possuem alguns ícones que fazem associação sistemática ao trabalho ou à função social. Ponderar esses objetos ou elementos representados permite considerar a relevância do trabalho na categorização social dos sujeitos e mesmo dos gêneros, o que não foi descartado por Meirelles em sua composição. São 58 aventais, entendidos como os panos que descem da cintura sobre as saias, geralmente brancos e que não chegam até o chão; quatro cestas; seis jarros; uma faca; quatro pandeiros; dois fusos de fiar; duas panelas; uma bolsa atada a um cinto na cintura; uma trouxa como a usada pelas rendeiras; um caderno e lápis na mão de uma figura com hábito religioso e, noutra, um rosário e, ainda, na mão da imagem feminina que é servida pela figura masculina, há um copo. Duas figuras estão diante do fogo. Todos esses ícones encontram-se associados às imagens representando o feminino. Nas imagens masculinas, tem-se: uma gaita de fole; uma rede; uma balança e uma caixa com instrumentos de medição; sete cintos transpassados no peito, sendo que, em dois, da mesma figura, há uma caixa e um saquinho anexados e, ainda, nesta figura há outro cinto na cintura acompanhado de um bolso maior; noutra prancha igualmente o cinto é transpassado no peito

\footnotetext{
${ }^{28}$ Segundo considerações de Gilles Lipovetsky que atribui o primeiro inventário de trajes às crônicas do conde de Zimmern. Cf. LIPOVETSKY, Gilles. O império do efêmero. São Paulo: Companhia das Letras, 1987, p. 31.
} 
e acompanha uma bolsa maior de couro; três bastões de peregrinos; seis varas de diferentes tamanhos e usos; três machados; uma enxada; dois copos; três recipientes para água; três selas; três livros; um rosário; três adagas; dois bandolins; três togas e dois papéis.

O que se conclui dessa quantificação das representações relacionadas às figuras é a reafirmação dos trabalhos tradicionalmente femininos associados à cozinha e ao trato da casa, com a grande quantidade de aventais desenhados nos trajes femininos; já, no masculino, o trato com a criação de animais se faz marcado pela presença majoritária de varas entre os ícones exibidos. Outro aspecto interessante a observar é que apenas em figuras masculinas vê-se a presença de togas e folhas de papel, indicando o domínio do saber pelo masculino. Há a presença de um caderno entre as figuras femininas, o que indica mais um trabalho de controle e registro, do que de leitura e estudo. Ainda cabe ressaltar que a figura que segura o caderno e lápis é uma freira, ou seja, para a mulher civil e campestre, a ideia da leitura e da escrita não correspondia a uma representação comum, enquanto os cestos e jarros predominam com dez aparições entre as 70 imagens do feminino produzidas por Victor Meirelles.

Das 104 pranchas coloridas, em sete figuras femininas não há um objeto de trabalho desenhado, enquanto nas figuras masculinas apenas duas não o tem, o que também indica que o masculino teria, em sua representação, quase uma exigência de distinção pelo trabalho. Portanto, as figuras femininas e masculinas representadas reafirmam a condição social de gênero normatizada para o século XIX ocidental, no qual mulheres ocupavam-se do ambiente doméstico e os homens das tarefas externas e, conforme posição social, das atividades ligadas ao saber e comando.

\section{Ícones da aparência corporal masculina}

Reunindo as 36 pranchas produzidas por Victor Meirelles que trazem uma figura masculina, foram depreendidos indícios do que se coloca como "próprio do homem" no começo da década de 1850, na percepção de um jovem brasileiro na Itália. Dessas 36 pranchas, oito foram descartadas nesta análise por conterem ícones que as associam facilmente à noção de traje de cena, ${ }^{29}$ seja pelo gestual ou datação e tipos de trajes presentes. São elas: as

\footnotetext{
${ }^{29}$ Terminologia estabelecida por Fausto Vianna. Segundo o autor: traje de cena é "a indumentária das artes cênicas. O termo, mais amplo que traje teatral, pode abranger trajes de teatro,
} 
MNBA 1592, 1627, 1617, 10358, 10362, 10634 e duas de colecionador particular. Ainda do grupo inicial, fica evidente que três pranchas tratam da mesma figura em posições e níveis de complexidade diferenciados. Para esse trio, então, foi considerada apenas uma ocorrência quanto aos aspectos observados nas análises: ${ }^{30}$ cobertura de cabeça; cobertura de tronco; cobertura de pernas; cobertura de pés; acessórios; e cores utilizados. Além disso, foi observado em relação à aparência corporal: no rosto, os quesitos de barba, bigode e cabelo, bem como a feição corporal. No quesito "cobertura de cabeça", constatou-se a presença majoritária de um chapéu de copa cônica - 12 ocorrências - seguida da presença de três barretes, duas espécies de boinas, uma cartola e um turbante, além das cinco figuras que trazem uma capa com capuz. No quesito "cobertura do tronco", a diversidade de peças e sobreposições permitiu que se observassem cinco variações: camisa, batina ou túnica, colete, casaco e capa. Assim, a "camisa branca", sem marca de um decote em especial, apareceu sete vezes e, com gola em V, seis vezes; a camisa de cor apenas uma vez e, tendo só os punhos ou gola, observam-se quatro repetições.

As "batinas e túnicas" aparecem devido à própria caracterização da figura que representa um traje religioso e, nesse caso, são seis batinas e duas túnicas que se apresentam. Os "coletes", por sua vez, aparecem em dez figuras e apenas um está sobreposto a um tipo de paletó. Os "casacos" tipo paletó se sobrepõem com dez ocorrências; em formato de fraque são apenas dois, tendo-se, ainda, um de couro com pelos. Por fim, neste grupo, aparecem as "capas": com palas há cinco e outras quatro com capuz; como pelerines, mais curtas, são três, sendo que há uma com capuz; por último, se observam duas longas e volumosas capas denominadas toga.

dança, circo, mímica e performance". Cf. VIANNA, Fausto. O traje de cena como documento. São Paulo: Estação das Letras e das Cores, 2015, p. 65.

${ }^{30}$ Proposta construída com base em DUFLOS-PRIOT, Marie-Thérèse (org.). Système descriptif du costume traditionnel français. Paris: Musée National des Arts et Traditions Populaires, 1988. 
rev. hist. (São Paulo), n. 178, a04618, 2019 http://dx.doi.org/10.11606/issn.2316-9141.rh.2019.144440
Mara Rúbia Sant'Anna

0 masculino nos traços e cores do jovem Victor Meirelles

\section{Figura 3}

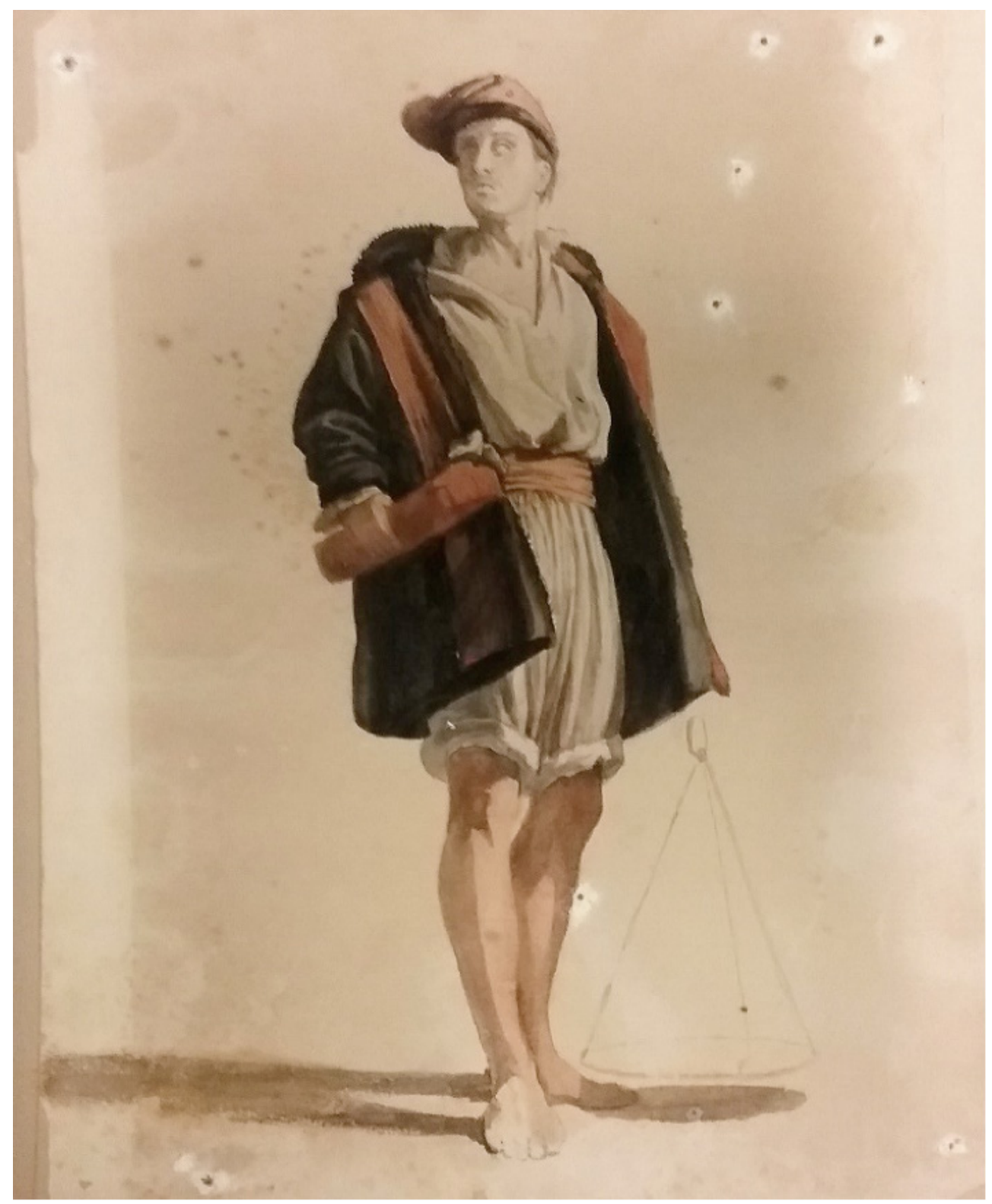

MEIRELLES, Victor. MNBA 1577. Aquarela sobre papel colado em cartão, 29,7 x 22,4 cm. Fonte: Museu Nacional de Belas Artes. 
No quesito "cobertura de pernas", apenas as figuras com batinas não apresentam calças, sendo que se evidenciam as calças com braguilhas num total de seis. Sobre uma dessas há uma calça mais curta ou avental com pelos. Observam-se seis figuras com calções abaixo do joelho e com braguilhas, e outra com um calção curto e meias colantes; três calças largas sem braguilhas; três com pelos. No quesito "cobertura de pés", ressalta-se uma espécie de solado com meia e tiras, num total de nove, seguido de sandálias somando seis; quatro espécies de bota; sapatos com fivelas e meias são apenas dois. Há, ainda, três descalços e dois pés que não aparecem. Por fim, no quesito "acessórios", pode-se constatar a presença de duas polainas, um lenço, sete faixas de cintura, sete tiras de couro transpassadas no peito, sendo que três delas estão com bolsas e quatro sem; e outros dois cintos acompanhados de bolsa.

Quanto às cores, há uma presença constante dos tons terrosos, sobressaltando-se o marrom em treze casos, acompanhado do laranja (dois casos), ocre (dois) e amarelo (três); o vermelho aparece sete vezes; o azul e o verde, quatro vezes cada um. O preto se apresenta oito vezes, havendo apenas dois casacos nesta cor, as demais peças são capas. Em branco se encontram doze peças. Sob outro ângulo observam-se as figuras, considerando a representação da masculinidade na "face", e constata-se a presença majoritária da barba, acompanhada de bigode em 14 figuras, sendo que numa figura ainda se vê uma longa barba branca contra doze que não têm nem um nem outro. Em relação ao cabelo, em dez figuras o mesmo não foi representado; uma o traz curto e outras duas em cima dos ombros; enquanto em quatorze figuras, o cabelo foi desenhado abaixo das orelhas.

Em relação à feição corporal, as figuras masculinas são representadas de maneira proporcional, tanto em relação à altura como à largura, isto é, nenhuma figura expressa um corpo baixo ou gordo. Nas pranchas MNBA 1630 e 1589, constatam-se representações de figuras com estatura menor e com feição mais jovial, reforçando a ideia, portanto, de se tratarem de adolescentes. Na prancha MNBA 1628, cuja composição indica um pescador, pode-se considerar um corpo mais magro que os demais. 


\section{Figura 4}

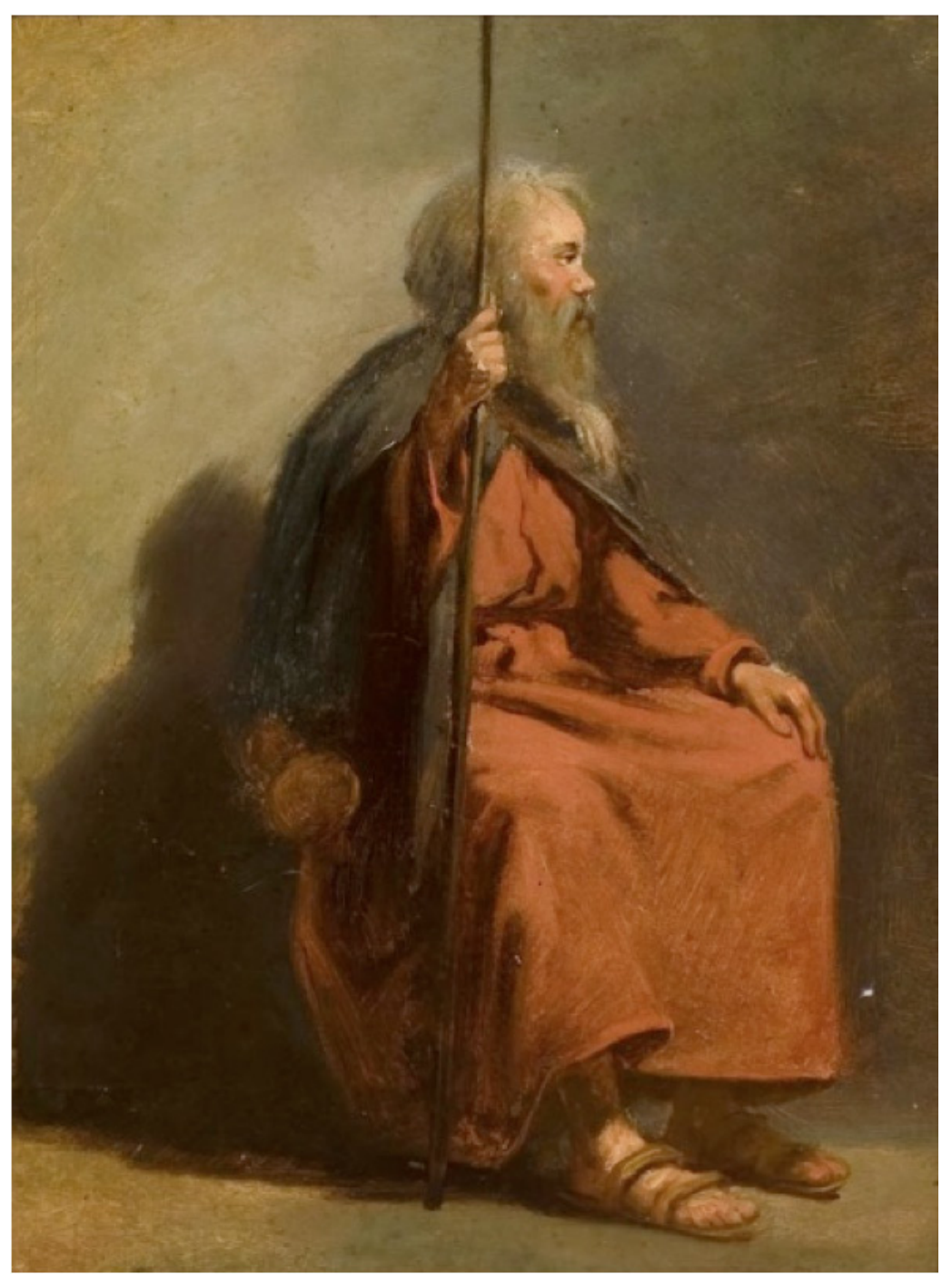

MEIRELLES, Victor. MNBA 10360. Óleo sobre papel, 27,7 x 22,2 cm, 18531856. Fonte: Museu Nacional de Belas Artes.

Por todos estes elementos, pode-se afirmar que as representações do masculino reforçam as noções dos trajes e aparência corporal próprios para este gênero, sendo a cobertura das pernas e do tronco majoritariamente feita de calças compridas acompanhadas de camisas, colete e espécie de paletó; nas faces, a barba e o bigode completam a noção de seriedade e respeitabilidade concebidas como próprias do homem. Como visto no item anterior, os 
objetos que completam a representação das figuras levam à associação do gênero masculino ao trabalho e às posições de comando, destacando-se a variedade de formas de trabalho e trajes próprios para cada uma das funções representadas. Além disso, há prazer conotado na figura que toca a gaita de fole e numa outra que brinda com o copo elevado, o que não se vê em nenhuma das 70 pranchas com figuras femininas.

\section{Figura 5}

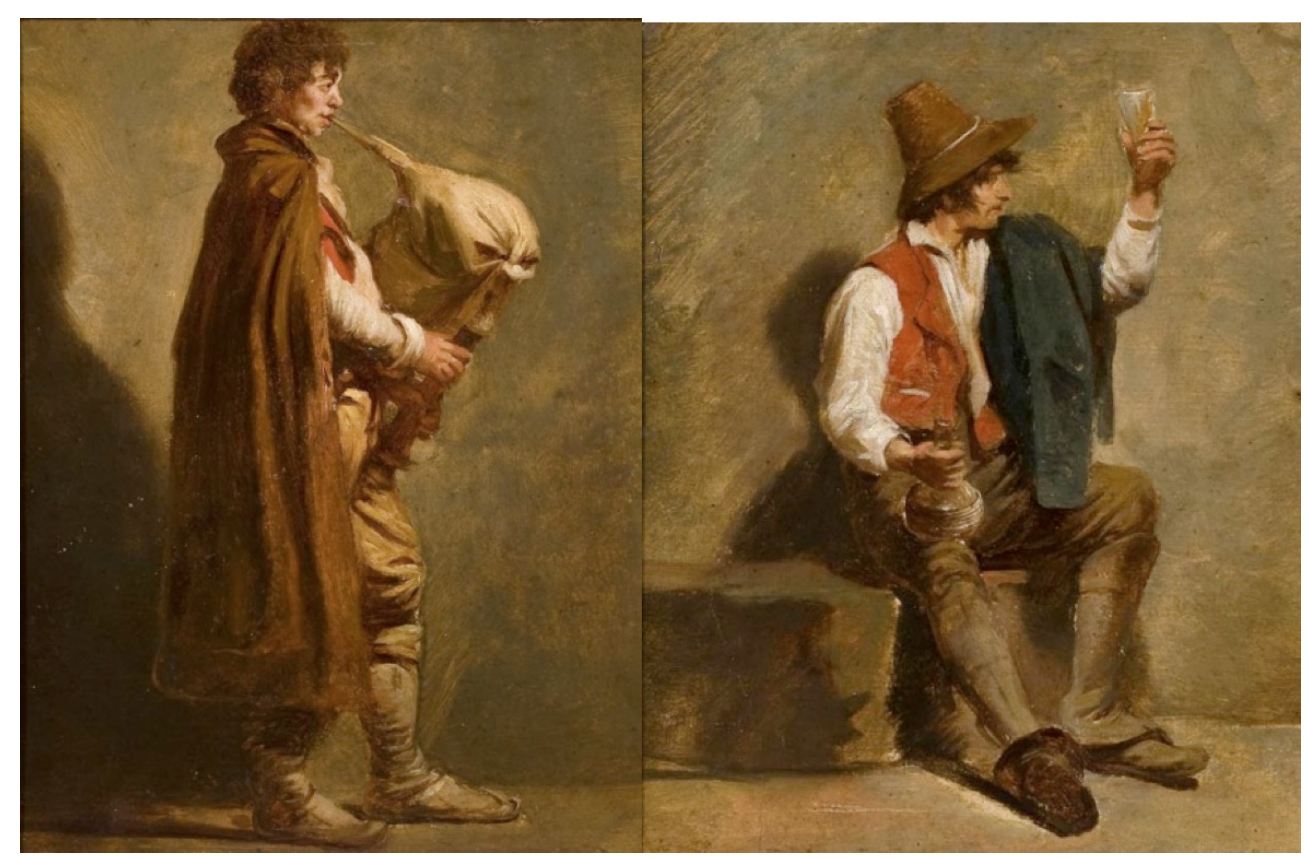

MEIRELLES, Victor. MNBA 10352 e MNBA 10357. Óleo sobre papel. $27,5 \mathrm{~cm}$ x 22,3 cm e 29,3 x 21,6. Fonte: Museu Nacional de Belas Artes. 


\section{Narrativas vestimentares}

Victor Meirelles produziu uma narrativa vestimentar do masculino a partir da composição concebida, como visto acima, seguindo uma tradição de formação artística do século XIX e de práticas de representação do pitoresco estimuladas pelos ideais românticos, em sua versão purista, bastante difundidos no Láscio e na Toscana à época. Ampliando a discussão, busca-se outra estrutura narrativa do mesmo vestir masculino, atentando para processos de intericonicidades que a escrita da história vestimentar do masculino produz.

Farid Chenoune, em seu livro Des modes et des hommes (CHENOUNE, 1993), ${ }^{31}$ de 1993, aponta que, a partir de 1835, surgiu o paletot, cuja primeira característica é de "não desenhar a cintura e dessa maneira renovar a ideia do sobretudo" (CHENOUNE, 1993). ${ }^{32}$ Inspirado nas pesadas vestes dos pescadores do norte francês, ele se define por não possuir a costura horizontal acima dos quadris, nem ter pences embaixo do braço nas mangas ou recortes e partes duplas no peito; menos ainda abas ou basques abaixo da cintura. $\mathrm{O}$ autor utiliza uma fotografia de Paul Nadar de 1860 e uma citação de Auguste Luchet de 1868 para ilustrar a descrição do paletó - que desenvolve com palavras e, especialmente, pela verve de Luchet -, reforçando a significação da nova peça do guarda-roupa masculino como um traje mais simples, mais democrático, de fácil acesso e que afrontou a noção de elegância e distinção que peças como o fraque e o redingote atribuíam aos homens que os usavam. O jornalista e escritor, condenado em 1842 por excitar a disputa entre as classes com seu romance Le nom de famille, escreveu o seguinte:

O tempo escultural dos Staub e dos Kléber [líderes da Revolução Francesa na Alsácia] não existe mais; ele morreu com o fraque e o redingote ajustado. O paletó saco sobre todos os ombros o suprimiu. Não há mais sob medida agora, há tamanhos (...). Não se é mais um cliente, se é um tamanho 80 (LUCHET, 1993, p. 65).33

Essa peça, versátil em seu uso e de fácil produção, tornou-se a roupa fundamental do guarda-roupa burguês. Iniciando o capítulo "Le paletot $\mathcal{E}$ la jaquette, 1850 -1914", a responsável pela iconografia da obra referente ao século XIX, Maryse Hubert, escolheu seis fotografias de homens conhecidos

\footnotetext{
${ }^{31}$ CHENOUNE, Farid. Des modes et des hommes. Paris: Flammarion, 1993.

32 Ibidem, p. 65.

${ }^{33}$ LUCHET, Auguste. L'art industriel à l'Exposition Universelle de 1867, p. 367. In: CHENOUNE, Farid. Des modes et des hommes. Paris: Flammarion, 1993, p. 65.
} 
e desconhecidos para ilustrar as folhas, fazendo, assim, um sumário com imagens que perpassam os tempos que o texto debate. A primeira das fotos é Baudelaire en paletot, 1855, marcando, desde essa primeira apreciação visual do capítulo, o tom que era dado na discussão do paletó no texto: um traje de irreverência e ruptura, próprio da boêmia e dos homens que se distanciaram da noção de ordem do século XIX europeu.

Ao longo do capítulo, foi destacado que a simplificação da confecção da peça central do traje masculino fez com que fosse possível a sua reprodução por profissionais menos hábeis que os mestres alfaiates. Com a difusão da máquina de costura e a ampliação do comércio por meio dos grandes magazines e o sistema ferroviário mais eficiente na França, a roupa masculina foi o primeiro segmento a ser amplamente atendido por uma indústria da confecção, permitindo, assim, que diferentes grupos sociais tivessem fácil acesso aos produtos de moda.

Facilitada pela fabricação simplificada, a difusão do paletó em diversos tecidos ocorreu ligeira e se firmou na escrita de literatos, nas folhas dos jornais e nas crônicas de moda do período como um traje de todas as horas para todos os homens. Contudo, ressalta a argumentação de Chenoune que o traje, tão popular, sempre fora combatido por alfaiates e outros especialistas que defendiam a sobrevivência de vestes mais sofisticadas. Dentre as fontes trazidas para reforçar o discurso historiográfico do pesquisador francês, é citado trecho do Journal des Tailleurs, de 16 de setembro de 1856, ano em que Meirelles partiu de Roma. Diz o jornal: "Sem dúvida as roupas largas são infinitamente cômodas, não se pode negar. Mas elas têm um grave inconveniente de ir bem a todo mundo; (...) o que as faz serem classificadas naturalmente sob o domínio da confecção". ${ }^{4}$

Em total contraponto a essas assertivas de Chenoune, a maioria dos livros de história da moda reforça a narrativa do vestir masculino do século XIX a partir da existência do estilo dândi, unificando todo um século de práticas vestimentares a um estilo para o qual o autor francês não atribui nem mesmo um subtítulo, senão quando opõe os petits crevés aos gentlemen victoriens, ${ }^{35}$ ou seja, os aficionados da moda versus os cultivadores de uma

\footnotetext{
${ }^{34}$ Apud CHENOUNE, Farid. Des modes et des hommes, op. cit., 1993, p. 67. No original: “Aprés tout les vêtements larges sont infiniment commodes, on ne peut le nier. Mais il ont le grave inconvénient d'aller bien à tout le monde; (...) ce qui les classe tout naturallement dans le domaine de la confection".

35 Ibidem, p. 71.
} 
elegância clássica. No livro de Bronwyn Cosgrave, ${ }^{36}$ de 2000, a tendência do traje masculino para os Novecentos é descrita como a marcada pela influência de George Brummell, de conde d'Orsay e do príncipe Albert. O dandismo se caracteriza por um cuidado detalhado da aparência, composto com sobriedade e eliminando os excessos de ornamentos, cores e volumes próprios dos trajes de origem aristocrática.

François Boucher ${ }^{37}$ indica, por sua vez, no livro referência História da moda no Ocidente, que a casaca foi simplificada na Europa da segunda metade do século XIX, sendo que o casaco cinturado e com basque, usado com cartola, ficou reservado para os jantares mais requintados. Também ressalta que a moda inglesa foi influenciada, a partir de 1850, pelo paletot francês. No final da década, o terno - casaco, colete e calça feitos do mesmo tecido - apareceu e, segundo o conservador do Museu Carnavalet, ${ }^{38}$ até os últimos anos do século XIX, este conjunto permaneceu um traje informal, usado apenas pela manhã, no campo ou para viajar. Igualmente, o autor informa sobre os costumes vestimentares de exceção praticados pelos intelectuais excêntricos ou pelos convidados requintados dos bailes das Tuileries, que reviviam estilos mais aristocráticos em pleno século XIX. Narra Boucher também que, enquanto o dandismo grassava pelos clubes e círculos fechados após 1850, mudanças nas cores e formas se fizeram, sutilmente, como a opção pelo preto nos casacos em oposição ao colorido, usado com calças ajustadas às pernas. Igualmente, os coletes em cores ou brancos foram substituídos por coletes pretos, acompanhados de camisas engomadas e gravatas borboletas em vez de lenços - os plastrons - cujo uso se tornou muito raro. Ainda, lembra Boucher que as botas sob medida foram substituídas com facilidade pelas fabricadas em Blois (França), a partir de 1850, de forma industrial. A partir de uma proposta menos simplificadora da pluralidade de práticas vestimentares, o autor de História da moda no Ocidente busca requintar sua argumentação, segmentando socialmente as formas de vestir e valorizando os trajes em diferentes grupos sociais.

${ }^{36}$ COSGRAVE, Bronwyn. História da indumentária e da moda - Da antiguidade aos dias atuais. São Paulo: Gustavo Gili, 2012. UK, 2001.

${ }^{37}$ BOUCHER, François \& DESLANDRES, Yvonne. A history of costume in the West. Londres: Thames and Hudson, 1987. $1^{\text {a }}$ edição, FR, 1965.

${ }^{38}$ Ver SANT'ANNA, Mara Rúbia. Era uma vez a moda...: algumas histórias para se lembrar. Revista Ciência e Cultura, vol. 62, n. 2, São Paulo, 2010, p. 33-35. Disponível em: <http://cienciaecultura. bvs.br/scielo.php?script=sci_arttext $\xi$ pid=S0009-67252010000200015\&lng=pt $\xi \mathrm{nrm}=\mathrm{iso}>$. Acesso em: 18 mar. 2018. 
Tais descrições divergem em muitos pontos daqueles que Carl Köhler ${ }^{39}$ descreve e detalha - expondo padronagem de corte das peças e fotografias de época - ao ressaltar a persistência do fraque e da casaca. Da mesma maneira, James Laver ${ }^{40}$ não dá qualquer importância para o paletó, e enfatiza a presença das casacas com sua variedade nos trajes masculinos. Considerando os autores citados, o narrado por meio de palavras não coincide entre eles e quanto mais "comercial" for o livro, como no caso de Cosgraves, mais simplificada e homogeneizante é a narrativa apresentada. Outrossim, o que se encontra nos diversos livros hoje disponíveis para o estudo da moda no Ocidente destoa do narrado por cores, traços e formas nas pranchas de Victor Meirelles e, como facilmente se deduz, isso se deve ao fato de os historiadores da moda centrarem suas narrativas sobre o espaço urbano e os grupos sociais mais elevados, aqueles consumidores e ditadores de tendências de moda, desconsiderando, quase sempre, o traje mais simplificado e menos submetido à obsolescência programada, própria dos produtos de moda num sistema capitalista avançado (SANT'ANNA, 2009). ${ }^{41}$

O traje regional, objeto de apreciação de ilustradores e artistas do século XIX como Pinelli e Gavarni (LANDRE, 1912), ${ }^{42}$ para citar apenas dois dos mais relevantes, tem definição imprecisa, como alerta Jean-Pierre Lethuillier. Inicialmente, foram denominados de trajes tradicionais no século XIX e começo do XX; por outro lado, foram adjetivados de popular "sem dúvida para fazer a distinção com a roupa das elites urbanas, parisienses, antes de tudo" (LETHUILLIER, 2009, p. 17). ${ }^{43}$ Nesses dois termos, o que se impõe, semanticamente, são as projeções da elite que aprecia os trajes dessa ordem como algo distante e até inferior aos seus; como algo próprio ao povo, uma categoria socialmente entendida como pobre e desprovida da cultura erudita. Todavia, como destaca Lethuillier, supor tal origem "pobre" dos trajes observados é desconsiderar a riqueza têxtil, a variedade de ornamentos e acessórios que os compunham, a necessidade de mão de obra especializada que os fabricavam e, ainda, as ocasiões festivas e especiais nas quais eram usados. Logo,

\footnotetext{
39 KÖHLER, Karl \& SICHART, Emma von. História do vestuário. $2^{a}$ edição. São Paulo: Martins Fontes, 2005. $1^{\mathrm{a}}$ edição, DE, 1877

${ }^{40}$ LAVER, James. A roupa e a moda: uma história concisa. São Paulo: Companhia das Letras, 1989. $1^{\text {a }}$ edição, UK, 1967.

${ }^{41}$ SANT'ANNA, Mara Rúbia. Teoria de moda. $2^{\text {a }}$ edição. São Paulo: Estação das Letras e das Cores, 2009.

${ }^{42}$ LANDRE, Jeanne. Gavarni. Paris: L. Michaud, 1912.

${ }^{43}$ LETHUILLIER, Jean-Pierre. Introdution. In: Idem. Les costumes régionaux: entre mémoire et histoire. Rennes: Presses Universitaires de Rennes, 2009, p. 17.
} 
o traje regional - denominação atual dos antropólogos e etnógrafos - foi, à época de seu uso, também composto de roupas submetidas aos ímpetos da distinção social, da renovação de formas e materiais no ritmo que o sistema de moda possibilitava naquele contexto histórico e social. Não obstante, os historiadores da moda em geral se fazem emissários de uma narrativa social do vestuário pelo olhar da elite e, nesse propósito, relegam os trajes regionais às páginas que consagram para falar da roupa popular, quando falam. Daí a estranheza diante das pranchas de Victor Meirelles.

Para finalizar essa discussão sobre tempos e imagens, traz-se, para a análise, duas ilustrações recorrentes nos livros citados acima com o propósito de aprofundar análise acerca das relações discursivas que se impõem na intermitência dos tempos, das narrativas e das imagens, nas possibilidades do que se vê, se entende e se aceita como possível de ser "o passado".

Em quatro das obras citadas anteriormente - Chenoune, Cosgraves, Boucher e Laver - a obra de William Powell Frith The derby day, ${ }^{44}$ de 1858, é utilizada para ilustrar didaticamente os estilos masculinos e femininos de vestir na Europa, no começo da segunda metade do século XIX. Nessa tela, observa-se a predominância dos manteaux, redingotes e alguns fraques e, também, das cartolas, acompanhadas de coletes de cor única, calças com braguilhas que são estreitas nas pernas; mas também calções e botas de montaria. Nos pescoços, colarinhos engomados e altos, com laços menos robustos que plastrons, completam os detalhes dos trajes masculinos das figuras centrais. Outra ilustração é a reprodução da obra de James Tissot Le Cercle de la rue Royale, ${ }^{45}$ de 1868, que aparece em dois livros: os de Chenoune e Boucher. No cenário construído com cuidado por Tissot, os trajes sofisticados de homens de posses são representados em detalhes: cartolas e bengalas, sapatos pretos reluzentes completam trajes compostos de calça, camisa, colarinhos altos, gravatas borboletas e paletós abotoados apenas no alto ou, completam o requinte, longos sobretudos.

Na ação pictórica desses dois pintores - Frith e Tissot - muito há em comum com o trabalho do jovem pintor brasileiro, tal como o cuidado minucioso na representação dos trajes e o anseio de registrar uma condição

\footnotetext{
${ }^{44}$ Para apreciar a tela acessar: http://www.tate.org.uk/art/artworks/frith-the-derby-day-n00615. Acesso em: 28 set. 2017. The derby day: the "first study" for the celebrated painting. Oil on canvas. 39.4 x $91.1 \mathrm{~cm}$. Londres: Tate Britain Museum.

45 Para observar acesse: http://www.musee-orsay.fr/fr/collections/oeuvres-commentees/recherche/commentaire_id/le-cercle-de-la-rue-royale-22193.html?no_cache=1. Acesso em: 29 set. 2017.
} 
histórica da realidade observada. A tela Dia de derby proporcionou acurados estudos $^{46}$ sobre a sociedade vitoriana, indicando a variedade dos tipos sociais e suas relações conflituosas sob a aura de uma alegre e costumeira festividade nacional inglesa. Da mesma forma, a tela de Tissot é apresentada, no próprio site do Museu d'Orsay, como estudo fiel dos costumes vestimentares daqueles personagen $s^{47}$ e, porque resultante de uma encomenda, teve como proposta reafirmar a condição de excelência e exceção do grupo de intelectuais franceses $d u$ Cercle.

Muito diferente dessas duas obras consagradas na pinacoteca europeia, a coleção de trajes italianos de Victor Meirelles, até o presente, não possuía estudos aprofundados a seu respeito e teve pequena projeção nas exposições realizadas. Em sua maioria, são pranchas pequenas, feitas em aquarela, em papel ordinário e sem um suporte dignificante como a moldura. Além disso, suas figuras não têm indicações precisas de quem são as personagens e nem das ocasiões em que foram observadas ou se este é o fato: tratar-se de tipos sociais observados in loco. Geralmente, consideradas como exercícios de um artista aprendiz, feitas mediante álbuns destinados à cópia ${ }^{48}$ ou coisa

\footnotetext{
${ }^{46}$ Como o texto bastante conhecido de COWLING, Mary. Victorian figurative painting: domestic life and the contemporary social scene. Papadakis Publisher, 2000.

47 Site do Musée d'Orsay, Ministère de la Culture, França. "Fils d'un marchand de mode et d'une modiste, Tissot a toujours accordé dans sa peinture une attention particulière aux vêtements. Le Cercle de la rue Royale lui offre toutes les opportunités d'exprimer cet intérêt et de faire preuve d'une extrême précision qui semble vouloir rivaliser avec la photographie. Costumes et accessoires rendus avec force détails témoignent des goûts de l'aristocratie des années 1860 tout en rappelant le statut social de ces hommes saisis dans un cadre prestigieux". Disponível em: <http://www.musee-orsay.fr/orsay.fr>. Acesso em: 17 set. 2017.

${ }^{48}$ Ver PEREIRA, Sonia Gomes. Arte, ensino e academia: estudos e ensaios sobre a Academia de Belas Artes do Rio de Janeiro. Rio de Janeiro: Mauad/Faperj, 2016. A professora Sônia Gomes Pereira defende que a formação artística do século XIX passava pela cópia de figuras contidas em álbuns, oferecidos pelos professores mestres aos aprendizes. Todavia, no caso de Victor Meirelles, a quantidade de pranchas, sua qualidade e o fato de algumas terem encontrado comercialização na época, como as pranchas em posse de colecionadores comprovam, levaram-me a descartar a possibilidade de serem cópias. Posteriormente, a partir do livro de De Sanctis sobre a vida e obra de Tommaso Minardi, a intuição dedutiva da pesquisa se confirmou. Ver DE SANCTIS, Guglielmo. Tommaso Minardi e il suo tempo. Roma: Forzani e C. Tipografi del Senato, 1900. De Sanctis informa a existência de um álbum com mais de 400 gravuras da Madona e da Sagrada Família disponibilizado aos estudantes, se requisitado no ateliê de Minardi. Tais imagens da virgem se fundamentam numa tradição pictórica muito apreciada pelos puristas e que Nicola Consoni, professor de Meirelles, também compartilhava. Portanto, considera-se que as pranchas de Meirelles não foram produzidas mediante imagens predeterminadas por seus mestres, talvez apenas tenha se inspirado no modelo de álbum, ou seja, criar para si um repertório de imagens que ele apreciava, como os seus mestres haviam feito com as imagens que eles consideraram relevantes.
} 
do tipo, quem estudou as obras de Victor Meirelles não se debruçou sobre as pequenas pranchas em aquarela.

Nas pranchas do jovem Meirelles de Lima, o preto não predomina nas cores e se o paletó se faz presente com seus tecidos pesados e cortes largos, muitos se estendem além do quadril. Os coletes aparecem, muitas vezes, sem o acompanhamento do paletó e somente um é preto. No pescoço, observa-se apenas uma figura trazendo um lenço que pouco se assemelha ao plastron, enquanto, nas demais, podem-se ver golas de camisas ou casacos ou mesmo nada; porém, sem qualquer gravata borboleta. Em relação às calças, ainda se preservam os calções e, mesmo as calças com braguilhas são largas e não ajustadas às pernas, como a norma urbana francesa ditava. Também a cartola se observa apenas uma vez, ao passo que o chapéu de feltro escuro e pontudo é o mais frequente.

\section{Finalizando as discussões}

Portanto, entre as narrativas estabelecidas nos livros mais recorrentes de história da moda, com suas escritas e ilustrações, e as pranchas de Victor Meirelles - mesmo considerando-se texto como o de Chenoune, mais atento às diversidades de costumes vestimentares -, não é possível estabelecer continuidades - apesar da datação e da delimitação geográfica próximas, ainda que se tenha tido o cuidado de desconsiderar as pranchas de trajes de cena - neste estudo do traje masculino.

Pode-se dizer que, neste texto, são arroladas três formas narrativas sobre o vestir masculino na segunda metade do século XIX europeu. No confronto entre as representações pictóricas do artista brasileiro e as descrições da historiografia sobre as tendências de moda para os anos de 1850, pouco se completa no trânsito entre olhar as pranchas, refletir sobre as descrições apresentadas e analisar as ilustrações recorrentes nos livros. Por outro lado, essas mesmas pranchas nos fazem pensar no quanto são restritas e mesmo autoritárias as descrições que se encontram registradas nos livros mais acessados de história da moda, por estabeleceram como geral algo que foi circunscrito a um país e, dentro deste mesmo, a um grupo social, ao meio urbano e aos desejos de representação dessas épocas por aqueles que tinham poder para tal: pintores que posteriormente se consagraram. Por essa perspectiva, poder-se-ia perguntar: onde estão os tipos rurais, regionais da Inglaterra e França, nas narrativas de Laver e Boucher? Onde está o homem simples da Alemanha de Köhler? 
Então, se se pensar a partir dessas desconfianças sobre o que os livros consagrados nos apontam como a "norma", logo pode-se considerar como viável a ponderação dos trajes representados nas pranchas do jovem Victor como algo que compunha a possibilidade da aparência corporal de homens do século XIX na Itália rural. Nesse confronto não são as verdadeiras formas de vestir que estão sendo buscadas, mas a desconstrução de uma maneira única e fechada de pensar que o passado encerra em si apenas um jeito de vestir de homens e de mulheres, idosos e jovens, crianças e adultos e, principalmente, se busca não deslocar a representação artística do seu lugar de concepção e circulação para, numa apropriação arbitrária, alisar todas as dobras desses distintos tempos. Eles se cruzam e se interpõem, mas nunca por uma simplificação de suas percepções e, sim, porque o passado interfere na maneira e nas possibilidades de ver no presente.

Assim, é necessário ressaltar que as pranchas de Victor Meirelles, mais simples e longe da consagração artística das obras de Tissot e Frith, nos indicam, nesse "agora", 49 outros trajes e temporalidades distintos porque provêm de um artista pouco consagrado mundialmente e cujo trabalho se encontra num suporte e temário que não foram autorizados a narrar o passado dos costumes vestimentares. ${ }^{50}$

E nesse olhar que insiste em ver apenas o que estamos adestrados a observar, para confortar leitores mais pragmáticos pode-se dizer que os indícios presentes nas representações do masculino feitas por Victor Meirelles reafirmam a noção do masculino associado ao trabalho campesino; mas, também, ao intelectual e ao de liderança, como no caso das figuras com toga e livros. Por outro prisma, somente as figuras masculinas são representadas bebendo ou tocando um instrumento musical, em expressão de alegria e prazer. As ausências desses ícones junto às figuras femininas reforçam ou impõem a noção de que para o feminino ficava reservado o trabalho ou o silêncio e ao masculino o direito do prazer e da alegria.

Para leitores mais desconfiados, pode-se dizer que as pranchas estão contidas de iconicidades que repercutem no tempo e atravessam as possibi-

\footnotetext{
${ }^{49}$ Agora, no sentido que lhe dá Walter Benjamim, tese 14, de Sobre o conceito de história: "A história é objeto de uma construção cujo lugar não é o tempo homogêneo e vazio, mas um tempo saturado de 'agoras". In: BENJAMIN, Walter. Magia e técnica, arte e política: ensaios sobre literatura e história da cultura. $7^{\mathrm{a}}$ edição. São Paulo: Brasiliense, 1994, p. 229.

${ }^{50}$ Essa questão é tangenciada pelos próprios processos do mercado de artes e seu papel na consagração de certos tipos de obra e artistas.
} 
lidades de ver, ${ }^{51}$ fazendo a sobrevida de uma narrativa do vestir masculino para grupos sociais menos abastados. Em todo caso, são imagens que compõem narrativas visuais possíveis de serem lidas porque, nos olhos que as veem, o dito e o visto de outros tempos e autores se impõem, construindo os sentidos habituais que relutamos em descartar e, assim, nos consolam ao apreendermos, nas cargas do nosso conhecer, o que pinçamos naquele relampejar irreversível dessas imagens que vêm do passado.

\section{Referências bibliográficas}

AGAMBEN, Giorgio. L'image immémoriale. In: Idem. Image et mémoire: Écrits sur l'image, la danse et le cinéma. Paris: Desclée de Brouwer, 2004, p. 97-110.

BARILLI, Renato. Storia dell'arte contemporanea in Italia: da Canova alle ultime tendenze, 1789-2006. Torino: B. Boringhieri, 2007.

BENJAMIN, Walter. Sobre o conceito de história. In: Idem. Magia e técnica, arte e política: ensaios sobre literatura e história da cultura. $7^{a}$ edição. São Paulo: Brasiliense. 1994.

BOUCHER, François $\mathcal{E}$ DESLANDRES, Yvonne. A history of costume in the West. Londres: Thames and Hudson, 1987.

CHENOUNE, Farid. Des modes et des hommes. Paris: Flammarion, 1993.

COLI, Jorge. Meirelles em Roma. In: Idem. Victor Meirelles, um artista do Império. Rio de Janeiro: Museu Nacional de Belas Artes, 2004.

COSGRAVE, Bronwyn. História da indumentária e da moda - Da Antiguidade aos dias atuais. São Paulo: Gustavo Gili, 2012.

COURTINE, J.-J. Foucault e a história da análise do discurso, olhares e objetos. Entrevista concedida a Nilton Milanez. In: FERNANDES, C. A.; CONTI, A.; MARQUES, W. (org.). Michel Foucault e o discurso: aportes teóricos e metodológicos. Uberlândia: Edufu, 2013.

COWLING, Mary. Victorian figurative painting: domestic life and the contemporary social scene. Papadakis Publisher, 2000.

DE SANCTIS, Guglielmo. Tommaso Minardi e il suo tempo. Roma: Forzani e C. Tipografi del Senato, 1900.

\footnotetext{
${ }^{51}$ Discussões da imagem imemorial que faz refletir sobre a impregnação da imagem de tempos que não lhe pertencem, como um cadáver que, mesmo sem conter vida, manifesta a vida que não se encontra mais ali, mas que um dia existiu, fazendo do cadáver não o morto, o que desapareceu, mas a permanência daquilo que persiste. Baseado em Nietzsche, trata-se do eterno retorno do mesmo e que, nos termos de Benjamim, faz de toda imagem sempre uma imagem dialética, porque jamais pode ser apreendida como livre de suas contradições. Ver AGAMBEN, Giorgio. L'image immémoriale. In: Idem. Image et mémoire: Écrits sur l'image, la danse et le cinéma. Paris: Desclée de Brouwer, 2004, p. 97-110.
} 
DEBRET, Jean-Baptiste. Costumes italiens dessinés à Rome en 1807. Paris: Louis-Marie Petit, 1809. Disponível em: http://catalogue.bnf.fr/ark:/12148/cv39136944z.

DIDI-HUBERMAN, Georges. Ante el tiempo: historia del arte y anacronismo de las imágenes. $4^{\mathrm{a}}$ edição. Buenos Aires: Adriana Hidalgo, 2015.

DIDI-HUBERMAN, Georges. O interminável limiar do olhar, capítulo 10. In: Idem. O que vemos, o que nos olha. São Paulo: Editora 34, 2010.

DIDI-HUBERMAN, Georges.Quand lesimages prennent position:l'oeil del'histoire, vol. 1, capítulo 2: La dysposition des choses: démonter l'ordre. Paris: Les èditions de Minuit, 2009.

DUFLOS-PRIOT, Marie-Thérèse (org.). Système descriptif du costume traditionnel français. Paris: Musée National des Arts et Traditions Populaires, 1988.

FUGIER, Anne Martin. La vie d'artiste au XIX siécle. Paris: Audibert, 2007.

GUINSBURG, J. (org.). O romantismo. $4^{\text {a }}$ edição. São Paulo: Perspectiva, 2011.

KÖHLER, Karl \& SICHART, Emma von. História do vestuário. $2^{\mathrm{a}}$ edição. São Paulo: Martins Fontes, 2005.

LANDRE, Jeanne. Gavarni. Paris: L. Michaud, 1912.

LAVER, James. A roupa e a moda: uma história concisa. São Paulo: Companhia das Letras, 1989.

LE CHANU, Patrick. Le drapé: carnet de dessins. Paris: La Bibliothèque de l'Image, 2002.

LETHUILLIER, Jen-Pierre. Introdution. In: Idem. Les costumes régionaux: entre mémoire et histoire. Rennes: Presses Universitaires de Rennes, 2009.

LUCHET, Auguste. L'art industriel à l'Exposition universelle de 1867. In: CHENOUNE, Farid. Des modes et des hommes. Paris: Flammarion, 1993.

LURATI, Ottavio \& BOLLA, Stefano. L'immagine della tradizione: ideologia e storia nel costume popolare: con la riproduzione di rari esempi ticinesi e svizzeri. Milão: Il Polifilo, 1990.

MARIANI, Valerio (apresentação). Costumi di Roma edintorni: 24 acquerelli della meta dell'Oottocento. Curatoria editorial de Roberto Peliti. Roma:Stabilimento Tipografico Julia, 1971.

MELLO JÚNIOR, Donatto. Análise da composição. In: ROSA, Ângelo de Proença \& PEIXOTO, Elza Ramos . Victor Meirelles de Lima: 1832-1903. Rio de Janeiro: Pinakotheke, 1982, p. 117-121.

PEREIRA, Sonia Gomes. Arte, ensino e academia: estudos e ensaios sobre a Academia de Belas Artes do Rio de Janeiro. Rio de Janeiro: Mauad/Faperj, 2016.

PÊCHEUX, Michel. Análise automática do discurso. In: GADET, Françoise $\mathcal{E}$ HAK, Tony (org.). Por uma análise automática do discurso: uma introdução à obra de Michel Pêcheux. Campinas: Editora da Unicamp, 1997, p. 61-162.

PIROTTE, Jean. Images et critique historique. In: JADOULE, Jean-Louis. L'histoire au prisme de l'image, vol. 1: L'historien et l'image fixe texte. Louvain/BG: Université Catholique de Louvain, 2002.

ROSA, Ângelo de Proença \& PEIXOTO, Elza Ramos. Biografia. In: Idem. Victor Meirelles de Lima: 1832-1903. Rio de Janeiro: Pinakotheke, 1982.

ROSSETTI, Bartolomeo. La Roma di Bartolomeo Pinelli: una città e il suo popolo attraverso feste, misteri, ambienti e personaggi caratteristici nelle più belle incisioni del pittor de Trastevere. Roma: Newton Compton, 1981. 
SANT'ANNA, Mara Rúbia. Teoria de moda. $2^{\mathrm{a}}$ edição. São Paulo: Estação das Letras e das Cores, 2009.

SANT'ANNA, Mara Rúbia. Era uma vez a moda.: algumas histórias para se lembrar. Revista Ciência e Cultura. São Paulo, vol. 62, n. 2, 2010, p. 33-35. Disponível em: <http://cienciaecultura.bvs.br/scielo.php?script=sci_arttextEpi$\mathrm{d}=$ S0009-67252010000200015Elng=ptE $\mathrm{nrm}=\mathrm{iso}>$. Acesso em: 18 mar. 2018.

SCARPA, Piero. La scuola romana di Tommaso Minardi segnò la fine in Europa del neoclassicismo in arte. Strenna dei Romanisti, n. 20, 1959, p. 235-242.

SILVESTRINI, Elisabetta. L'abbigliamento popolare italiano. Ricerca Folklórica, n. 14. 1986, p. 5-44.

\section{Sites e fontes para imagens}

MEIRELLES, Victor. Estudo de trajes italianos. [Diversos]. Museu Victor Meirelles. Florianópolis, SC. Disponível em: <http://museuvictormeirelles.museus.gov.br/ acervos/colecao-victor-meirelles/>. Acesso em: 18 mar. 2018.

MEIRELLES, Victor. [Diversas obras, porém nenhum estudo de trajes digitalizado] Disponível em: <http://www.mnba.gov.br/portal/colecoes/pintura-brasileira>. Acesso em: 18 mar. 2018.

FRITH, Willian P. The derby day: the "first study" for the celebrated painting. 1858. Óleo sobre tela. 39.4 x $91.1 \mathrm{~cm}$. Londres. Tate Britain Museum. Disponível em: $<$ http://www. tate.org.uk/art/artworks/frith-the-derby-day-n00615>. Acesso em: 28 set. 2017.

TISSOT, James. Le Cercle de la rue Royale, 1868. Óleo sobre tela, 174,5 x 280 cm. Musée d'Orsay. Disponível em : <http://www.musee-orsay.fr/fr/collections/ oeuvres-commentees/recherche/commentaire_id/le-cercle-de-la-rueroyale-22193.html?no_cache=1>. Acesso em: 29 set. 2017.

VIANNA, Fausto. O traje de cena como documento. São Paulo: Estação das Letras e das Cores, 2015. 